\title{
A trajetória de um líder comunista: Edvaldo Ratis e o Sindicato dos Gráficos
}

\author{
Maria do Socorro de Abreu e Lima* \\ Luiz Anastácio Momesso**
}

Resumo: Este artigo analisa a trajetória de um trabalhador gráfico, Edvaldo Ratis, líder sindical que atuou entre 1945 e 1964 na cidade do Recife. Desenvolveu intenso trabalho com vistas a organizar, politizar e mobilizar a classe operária por meio do jornal da categoria denominado O Gráfico. Como militante do Partido Comunista, procurava defender suas propostas no âmbito sindical e também no plano da política mais geral. Em 1963 lidera importante greve, numa conjuntura de avanços para os trabalhadores. Preso algumas vezes, deixou a presidência do sindicato com o golpe militar de 1964.

Palavras-chave: trabalhador gráfico; sindicato; Edvaldo Ratis.

Abstract: This article analyses the trajectory of a graphical worker, Edvaldo Ratis, a trade union leader who acted between 1945 and 1964 on the city of Recife. He developed an intense work intending to organize, politicize and mobilize the working class, through the newspaper for this category, named O Gráfico. As a militant on the Communist Party, he tried to defend his proposals on the trade union sphere, as well as in general politics. In 1963, he leads an important strike, in a conjuncture of improvements for the workers. Arrested a few times, he left the presidency of the Trade Union with the Military Coup, in 1964.

Keywords: graphic worker; trade union; Edvaldo Ratis.

Desenvolver um estudo biográfico sobre um dirigente sindical constituiu-se num grande desafio. Na verdade, a pesquisa que vem sendo realizada é a respeito do Sindicato dos Gráficos do Recife, entre 1945 e 1964, dentro de uma proposta de ampliação do conhecimento acerca do movimento operário no Brasil nesse período. Falar da organização, reivindicações e lutas de uma categoria não significa,

* Doutora em História pela Universidade Federal de Pernambuco (UFPE). Professora Associada do Departamento e do Programa de Pós-Graduação em História da UFPE.

** Doutor em Ciências da Comunicação pela Universidade de São Paulo (USP). Professor Associado do Departamento de Comunicação Social da Universidade Federal de Pernambuco (UFPE). 
porém, negligenciar a atuação específica de suas lideranças, até porque se elas incorporam e expressam os interesses gerais de classe, procuram, com base em sua visão de mundo, em suas análises e propostas, influenciar e conquistar, a partir das disputas de ideias e de seu empenho pessoal, a direção política daquela categoria no plano dos encaminhamentos práticos e organizativos, assim como contribuir de modo geral na organização da classe trabalhadora como um todo.

Este artigo trata da atuação política de um militante do Partido Comunista, Edvaldo Ratis, entre a redemocratização de 1945 e o golpe de 1964, que, a partir da sua militância sindical desenvolveu intenso trabalho com vistas à organização e mobilização de sua classe. Bastante dedicado à causa em que acreditava, impetuoso em alguns momentos, contraditório em outros, sua trajetória pode ser acompanhada com base nos artigos que escrevia para o jornal da categoria denominado O Gráfico, geralmente como secretário desse veículo de comunicação, mas não como membro da diretoria, cargo que só veio a ocupar no final dos anos 1950. A documentação sobre sua pessoa encontrada nos arquivos do Departamento de Ordem Política e Social de Pernambuco também foi de grande valia para acompanhar sua trajetória militante, seu posicionamento como comunista que buscava implementar as decisões do seu partido, fornecendo indícios sobre sua participação sindical ainda no final dos anos 70.

Falar sobre esse período, conhecido como populista, implica em pontuar algumas questões suscitadas pelo uso desse conceito, como a de manipulação das massas, através da qual a classe trabalhadora, particularmente a urbana, passou a participar mais ativamente do jogo político institucional, embora o Estado procurasse cooptá-la e mantê-la dentro de certos padrões de controle e limites. Desenvolvido de maneira mais expressiva por Otávio Ianni e Francisco Weffort, este último, contudo, também afirma que:

\begin{abstract}
Em realidade, o populismo é algo mais complicado que a mera manipulação e sua complexidade política não faz mais que ressaltar a complexidade das condições históricas em que se forma. O populismo foi um modo determinado e concreto de manipulação das classes populares, mas foi também o modo de expressão de suas insatisfações. Foi, ao mesmo tempo, uma forma de estruturação do poder para os grupos dominantes e a principal forma de expressão política da emergência popular no processo de desenvolvimento industrial e urbano. Foi um dos mecanismos através dos quais os grupos dominantes exerciam seu domínio, mas foi também uma das maneiras através das quais esse domínio se encontrava potencialmente ameaçado. ${ }^{1}$
\end{abstract}

Esse tipo de análise é duramente criticado por alguns autores da corrente revisionista, que propõem a substituição do termo populismo por trabalhismo. Felipe Demier, ${ }^{2}$ em estudo a respeito, questiona essa corrente, entre outros motivos, por analisar, com raras exceções, a questão do populismo de forma simplista, ou mesmo inconsistente, como se as massas populares apoiassem as lideranças varguistas como uma simples opção racional, positivando, portanto, "o engenhoso trabalhismo construído por Vargas, Marcondes Filho e cia." no final do Estado Novo. 
Quanto à corrente campineira, que vem promovendo estudos mais aprofundados sobre os trabalhadores e, a partir daí, constatando sua capacidade de organização e de luta naquele período, o autor chama a atenção para o fato de que, ao positivar a ação dos trabalhadores nas suas lutas por direitos, sofrem uma significativa influência da ideologia da cidadania, de viés liberal, amalgamando ecleticamente noções como "luta de classes" e "cidadania", "hegemonia" e "luta por direitos", num processo um tanto acrítico de uso de conceitos. ${ }^{3}$

Assim sendo, em que pesem as dubiedades e os limites, o termo populismo parece ainda válido, desde que se esclareça e problematize o que se pretende analisar.

Tratar de uma liderança sindical de nível intermediário implica recorrer a Antonio Gramsci, que teoriza a respeito do papel dos intelectuais orgânicos realçando sua importância na construção de uma contra-hegemonia que possa fazer frente às concepções burguesas presentes na sociedade e levada a efeito pelo proletariado através de seu partido. As atividades de organizar uma categoria e o movimento sindical, analisar a realidade em que se dão os conflitos concretos da luta de classes, elaborar as táticas para conduzir as lutas exige, além da disposição militante, uma atividade intelectual intensa e constante. Ao discorrer sobre a formação dos intelectuais especializados, Gramsci coloca questões que podem ser aplicadas, de certo modo, para os militantes que exercem também funções de dirigentes: "O modo de ser do novo intelectual não pode mais consistir na eloquência, motor exterior e momentâneo dos afetos e das paixões, mas num imiscuir-se ativamente na vida prática, como construtor, organizador, "persuasor permanente", já que não apenas orador puro (...)".4

Ter como foco a atuação de um trabalhador gráfico implica caracterizar meIhor essa classe. Conforme afirma Thompson, "a classe acontece quando alguns homens, como resultado de experiências comuns (herdadas ou partilhadas), sentem e articulam a identidade de seus interesses entre si, e contra outros homens cujos interesses diferem (...)". ${ }^{5}$ Porém, acrescenta que "a consciência de classe é a forma como essas experiências são tratadas em termos culturais: encarnadas em tradições, sistemas de valores, ideias e formas institucionais". ${ }^{6}$ Trabalhando com o conceito de experiência, Thompson procura realçar o papel dos homens como sujeitos "propondo, portanto, como princípio de análise e conexão as relações de produção e a consciência de classe por meio da mediação da experiência". ${ }^{7}$

Partindo desses pressupostos, buscamos caracterizar o setor gráfico de Pernambuco e as experiências políticas já vividas por essa categoria em Pernambuco.

O setor gráfico era, então, um ramo de atividade secundária no volume da economia, marcada pelas exportações do café e, em Pernambuco, do açúcar, embora fosse uma área de produção indispensável como suporte para o conjunto do desenvolvimento econômico e social. O rádio, que já era popular desde a década de 40, vivia sua época de ouro. Ainda assim, a maior parte da comunicação social jornais, revistas, almanaques, etc.- era veiculada pelos meios impressos. Também os livros, tão necessários para o desenvolvimento da ciência, para a preparação da

6 THOMPSON, E. P. A formação da classe operária inglesa, p.10.

7 MATTOS, Marcelo Badaró. E. P. Thompson e a tradição de crítica ativa do materialismo histórico. Rio de Janeiro: Editora UFRJ, 2012, p.86. 
força de trabalho mais qualificada e para elevar o nível cultural da sociedade, para veicular as correntes de pensamento laico e religioso, passava pela produção de impressos.

Essa produção demandava que pelo menos uma parte de sua força de trabalho fosse altamente qualificada. Nesse contexto, a categoria dos gráficos, além do domínio das letras, era privilegiada em termos de informação, e muito próxima da atividade jornalística. O jornalismo todo passava pelos gráficos, resultando que muitos gráficos também se tornavam jornalistas, não sendo incomum a identificação profissional como gráfico e jornalista.

$\mathrm{Na}$ época, a atividade jornalística não era resultado de uma formação acadêmica específica. A pessoa se tornava jornalista a partir de conhecimentos que possibilitavam o exercício dessa atividade e de seu efetivo exercício, para o que bastava escrever um artigo e tê-lo publicado em algum jornal ou revista e anexá-lo ao pedido de reconhecimento profissional. Existiam os jornalistas que viviam da profissão e os que se mantinham exercendo outras atividades profissionais, e que também praticavam o jornalismo.

Além de bem informados, pois, como já dito, a atividade de comunicação social passava pelo trabalho dos gráficos. A produção de livros os colocava em contato permanente com o conhecimento científico, com a literatura, com as correntes de pensamento, enfim, com a cultura. Daí também a identificação de gráfico intelectual, de gráfico escritor, poeta.

$\mathrm{Na}$ imprensa das associações de trabalhadores gráficos, o incentivo à busca da cultura coloca-se, em todo momento, como requisito para se tornar um bom profissional. Entre as atividades desenvolvidas pelas entidades sindicais sempre se dava destaque àquelas que contribuíam para elevar o nível cultural de seus associados como fazer teatro, organizar bibliotecas, inclusive academias de letras da entidade, o que fazia com que se tornassem referência e influenciassem outras categorias no mesmo sentido. Ser culto era colocado como uma característica que abria caminho para se tornar um bom profissional.

No campo sindical e da política, existiram nomes de destaque ligados ao ramo como Everardo Dias, gráfico, líder sindical e pensador socialista, e Edgar Leuenroth, gráfico, jornalista e líder sindical anarquista. Em Pernambuco, foi referência, no início do século XX, o tipógrafo, militante e organizador socialista João Ezequiel. Como organizador dos trabalhadores, ainda bem jovem assumiu a presidência da União Typographica, primeira organização dos tipógrafos de Pernambuco, criada em 1891, e que, em 1901, passou a se chamar Conciliação e Abrigo dos Artistas Gráficos. Essa entidade se propunha defender os interesses da categoria e a liberdade de imprensa. ${ }^{8}$ Considerando importante participar da política partidária, João Ezequiel conseguiu eleger-se deputado estadual entre os anos de 1912 a 1915, em aliança com o governo do general Dantas Barreto. Rezende apresenta de forma bastante crítica essa atuação e de fato, é necessário levar em conta os limites para o exercício de uma legislatura por parte de uma liderança dos trabalhadores. ${ }^{9}$ No plano sindical, porém, percebemos que os trabalhadores gráficos dos anos 50 o tinham em elevada conta.

Nos anos 30, quando é fundado o Sindicato Gráfico de Pernambuco, já são os comunistas que lideram o movimento sindical e que, também como os

8 FANCELLO, Maria Soares e Moura. "Os herdeiros de Gutemberg: processo representacional entre tipógrafos de Pernambuco". (Dissertação de Mestrado, Universidade Federal da Paraíba, 1995), p.29.

9 REZENDE, Antônio Paulo de Moraes. "A classe operária em Pernambuco: cooptação e resistência (19001922). (Dissertação de Mestrado em História, Universidade Estadual de Campinas, 1981), p.53. 
socialistas, defendem a participação nos processos eleitorais. Assim é que, para as eleições municipais de 1935, concorreram sob a chapa proletária denominada "Trabalhador, Ocupa teu Posto" três candidatos, sendo um deles o gráfico Chagas Ribeiro. Apesar de os três terem sido eleitos, ficaram presos vários meses, sem processo. Por fim, foram empossados, porém, logo depois, foi decretada a dissolução de todos os parlamentos com a instauração da ditadura do Estado Novo e os vereadores comunistas retornaram à prisão. Chagas Ribeiro escreveu o primeiro romance proletário de Pernambuco, chamado Mocambo. ${ }^{10}$ Também Calinício Correia, diretor do Sindicato dos Gráficos, havia se candidatado em 32, embora não tivesse sido eleito. ${ }^{11}$

Ao longo de sua história, parte dos trabalhadores assumiu uma postura conciliadora, submissa em relação aos patrões e temerosa de partir para um enfrentamento maior. O que não quer dizer, necessariamente, que não tentasse, de alguma forma, atuar com vistas a obter vantagens. Assim é que, particularmente a partir da chegada de Getúlio Vargas ao poder, com a criação do Ministério do Trabalho e da legislação trabalhista, inclusive alguns militantes da causa proletária optaram por esse caminho, integrando-se ao processo de organização dos trabalhadores a partir do Estado, e que vai se consolidar ao longo dos anos 40 do século XX.12 Outra parte, contudo, tinha um posicionamento mais crítico e radical em relação ao sistema capitalista, denunciando sua exploração e conclamando os trabalhadores à luta, nem sempre sob a forma de greve dada a conjuntura e as contradições efetivamente presentes em cada momento.

Nos anos 50, a categoria dos gráficos teve destaque nas grandes mobilizações da classe operária nas regiões de maior concentração de trabalhadores, assim como se empenhou ativamente nas lutas mais gerais por reformas que se colocavam então.

É tradição no meio sindical assim como nos partidos de esquerda desenvolver seus próprios meios de comunicação. Isto porque as informações, suas análises e enfoques não são neutros. Anarquistas, socialistas e comunistas sempre procuraram, através de sua imprensa, informar e formar, influir e liderar a classe trabalhadora com vistas a um processo de emancipação. O que também faziam os setores conservadores, como os Círculos Operários, o sindicalismo amarelo, os ministerialistas, nesse caso defendendo a ideia de harmonia entre capital e trabalho, realçando interesses e necessidades comuns, buscando negar a luta de classes.

De acordo com Mattos, tendo por base os escritos de Lênin, "os Partidos Comunistas construídos a partir da referência soviética (...), buscaram desenvolver seus instrumentos de formação, informação e propaganda. Deles, o jornal (...) foi certamente o mais valorizado". ${ }^{13}$ No que diz respeito ao gráfico a quem procuro retratar, durante toda a sua atuação no sindicato a imprensa sindical constituiu-se em sua principal preocupação.

No caso do PCB, a partir da redemocratização de 45, além de uma imprensa partidária própria, interna aos seus filiados, também desenvolveu uma imprensa 
de massas, com base em vários jornais diários editados em diferentes estados do país. Em Pernambuco, esse veículo de comunicação chamava-se Folha do Povo, cujo primeiro número circulou ainda em 1935, deixando de circular com a intensa repressão que adveio após a decretação da ilegalidade da Aliança Nacional Libertadora. Para boa parte da militância comunista era considerado não só como um veículo de informação, mas um meio de divulgação das diretrizes do partido, sendo importante para ampliar a influência deste entre amplas massas, inclusive com vistas a futuros recrutamentos. Organizar mutirões para a venda do jornal, em algumas ocasiões, ou entregá-lo a um conhecido ou companheiro de trabalho eram mecanismos utilizados pela militância no geral, em que pesem as perseguições, eventuais ou frequentes, conforme o momento político ou os interesses do governante e seu secretário de Polícia. Assim descreve Paulo Cavalcanti, rememorando situações de destruição do maquinário do jornal, o sentimento de um de seus funcionários:

Vi Waldu Cardoso, gráfico da Folha do Povo, ex-deputado comunista à Assembleia Constituinte de 1947, afagar com a mão, comovido, como quem acarinhasse uma criança, a linotipo avariada pela polícia, a linotipo em que ele exercia diariamente a sua profissão, a sua linotipo, diante da qual, pitando seu cigarro até o último trago, compunha as linhas de chumbo, lendo e comentando as matérias que vinham da redação.

Para todos nós aquelas máquinas representavam um organismo vivo, pulmões e cérebro de um verdadeiro combatente político, dando de si o melhor nas árduas refregas pela liberdade e pela democracia.

Tal e qual os jornalistas e gráficos da Folha, que se curavam das feridas das pelejas da noite para o dia, voltando às trincheiras de sempre, também elas retornavam céleres à sua labuta, emendadas aqui, soldadas acolá, ferro velho que o fragor de uma guerra cotidiana não oxidava. ${ }^{14}$

Edvaldo Ratis também foi funcionário do jornal Folha do Povo no início dos anos 60. Sua segunda prisão, inclusive, deveu-se a essa condição. Por ser uma liderança sindical desenvolveu importante atuação redigindo artigos para 0 Gráfico, órgão oficial do sindicato. Na função de redator, escrevia matérias voltadas tanto para questões mais imediatas e conjunturais como também associando essas questões a análises mais de fundo, com vistas a ampliar o conhecimento e a capacidade de análise da categoria. Mesmo quando fazia oposição, ou não estava à frente do sindicato como diretor, continuava escrevendo e editando o jornal. Nesse sentido, chama a atenção sua dedicação a essa tarefa, o que nos permite supor ser fruto de seu compromisso com a comunicação sindical. Faz-se necessário reconhecer, porém, que muitos outros militantes gráficos escreviam também para o jornal.

Alguns manuscritos feitos por Ratis chamam a atenção por seu posicionamento político-ideológico. A análise do material permite considerar que o conteúdo representa a palavra do PCB, porém a maneira de redigir, as comparações que faz, a linguagem compreensível para o povo mais simples que usa torna possível considerar sua origem e seu empenho em divulgar, de forma mais adequada, aquelas propostas.

Edvaldo Ratis nasceu no Recife em 1926 e filiou-se ao PCB em 1946, conforme consta em seu prontuário do DOPS. ${ }^{15}$ Sua primeira prisão ocorreu em 1952, aos 25

14 CAVALCANTI, Paulo. Nos tempos de Prestes (o caso eu conto como o caso foi - memórias políticas). Recife: Editora Guararapes, 1982, p.73.

15 Fundo SSP/DOPS/APEJE. Prontuário Edvaldo Ratis nº. 18.439. 
anos. A segunda em 1962, e a terceira em 1964, quando do golpe militar. Desta feita ficou incomunicável "durante aproximadamente quinze dias, sofrendo as costumeiras torturas adotadas na época (surras, choque elétrico, afogamento, ameaças de morte, etc.)". ${ }^{16}$ Teve seus dentes superiores fraturados, fato que foi denunciado à época no livro Torturas e torturados, de Márcio Moreira Alves. ${ }^{17}$ Ao longo da ditadura continuou sendo vigiado pelo DOPS, o que se constata com base em dois informes à Secretaria de Segurança Pública, um ainda em 1964, após sua saída da prisão, e outro em 1979, tendo em vista, entre outras coisas, a criação de um Conselho Sindical de Trabalhadores. ${ }^{18}$

Sua entrada no partido deu-se, portanto, num período de intensas mobilizações, quando o PCB, na legalidade, propunha uma política de frente ampla, considerada fundamental para garantir a conquista da democracia. Naquele momento o partido alia-se ao movimento "queremista", defendendo a proposta de “Constituinte com Getúlio”. Porém, este termina sendo deposto no final de 1945.

O partido priorizava, nesse momento, as eleições presidenciais e legislativas, que vieram a ocorrer em dezembro de 1945, assim como a organização do movimento sindical, para o que criou o Movimento Unificador dos Trabalhadores - MUT, em abril do mesmo ano, o que contou com a participação de líderes sindicais de 13 estados, entre os quais Pernambuco, defendendo, entre outras coisas, "a mais efetiva democracia sindical, assegurando a plena manifestação de opiniões em nossas assembleias e o rigoroso cumprimento de nossas resoluções efetivas" (...). ${ }^{19}$ Realçar esse item nos parece importante na medida em que não foram poucas as disputas entre a proposta de levar a luta democrática e, nesse sentido, priorizar a aliança de classes, defendida pelo PCB, e a pressão efetiva dos trabalhadores procurando organizar greves e agitações em defesa de suas reivindicações mais prementes. Os militantes comunistas ficaram, em grande parte, com suas categorias, na luta em defesa de seus interesses mais sentidos e imediatos. Durante os dois anos de legalidade, esse partido foi importante referência nacional, em especial para a classe trabalhadora.

Nas eleições de 1946, seu candidato a presidente, Yedo Fiúza, teve 9,7\% dos votos, elegeu ainda Luiz Carlos Prestes como senador e 14 deputados federais, sendo três de Pernambuco: Agostinho Dias, Alcedo Coutinho e Gregório Bezerra, dirigente do partido de origem camponesa. ${ }^{20}$ Para a Assembleia Constituinte desse mesmo estado o PCB elegeu nove deputados, ${ }^{21}$ dentre os quais uma mulher, Adalgisa Cavalcanti. Gregório Bezerra relata um fato ocorrido em Catende, município da Mata Sul de Pernambuco, durante essa campanha:

Os senhores de engenho, na vã tentativa de frustrar o nosso comício, ofereceram um churrasco aos trabalhadores rurais e aos operários da usina. Sabendo disso, transferimos o comício das $3 \mathrm{~h}$ da tarde para as $7 \mathrm{~h}$ da noite. Os trabalhadores comeram bastante churrasco, que há muito tempo não comiam carne. E às 7 h foram todos para o comício, de barriga cheia, e assim puderam ouvir melhor a propaganda eleitoral e do partido. (...) E quando, de propósito, me referi ao churrasco, a massa de trabalhadores caiu na gargalhada. Eles pediram que voltássemos a

16 Arquivos da Comissão da Memória e da Verdade. D. Helder Câmara/CEPE. Processos de Indenização.

17 ALVES, Márcio Moreira. Torturas e Torturados. Rio de Janeiro, 1965, p.62.

18 Fundo SSP/DOPS/APEJE. Prontuário individual nº.18.439.

19 TELLES, Jover. O movimento sindical no Brasil. São Paulo: Livraria Editora Ciências Humanas, 1981, p.23.

20 PACHECO, Eliezer. O Partido Comunista Brasileiro (1922-1964). São Paulo: Editora Alfa-Ômega, 1984, p.187.

21 CAVALCANTI, Paulo. O caso eu conto como o caso foi: memórias políticas, $2^{\circ}$ volume. Recife: Guararapes, 1980, p.109. 
realizar outros comícios em Catende, porque só assim teriam oportunidade de comer carne de novo, à custa dos patrões. E aproveitamos para dizer aos trabalhadores que aquela carne que eles comeram já tinha sido paga, milhares de vezes, por eles mesmos. ${ }^{22}$

Os comunistas eleitos procuraram marcar sua atuação defendendo projetos de interesse dos trabalhadores, e contrapondo-se tenazmente às propostas levadas pelos políticos conservadores. E mesmo reafirmando seu compromisso com a manutenção da ordem, eram considerados por muitos como subversivos, e atuaram sempre sob ameaça de cassação já que, ainda em março de 1946, foi solicitada a instauração de um processo nesse sentido. As arbitrariedades se intensificaram: "prisões, violações de imunidades parlamentares, invasão de sedes, (...) proibição de comícios, suspensão das atividades da Juventude Comunista e empastelamento da imprensa do PCB". ${ }^{23}$ Por fim, em 1948, todos os comunistas eleitos foram cassados. Com o partido na ilegalidade, ficou claro que a democracia nesse período enfrentaria uma série de limites, já evidenciados no impedimento do voto dos analfabetos, na manutenção da legislação trabalhista que atrelava o funcionamento dos sindicatos ao Ministério do Trabalho, na falta de uma legislação que claramente estendesse os direitos trabalhistas ao meio rural, no uso da Lei de Segurança Nacional, entre outros.

Do ponto de vista sindical, o governo Dutra, com base no Decreto-Lei $n^{\circ}$ 9.070, limitou bastante as possibilidades de serem decretadas greves. Esse mesmo governo, com o início da política da Guerra Fria, em 1947, fecha a Confederação dos Trabalhadores do Brasil, criada em 1946 e, utilizando-se da própria legislação trabalhista, fez intervenções em muitos sindicatos combativos, tirando suas diretorias eleitas e colocando em seu lugar juntas governativas.

Em Pernambuco, o jornal Folha do Povo traz um artigo, no início de 1947, repudiando "a circular-monstro da $8^{\mathrm{a}} \mathrm{DRT}$, que proíbe aos sindicatos contribuírem financeiramente para a USTEP e a CTB por se tratar de órgãos ilegais". ${ }^{24}$ E publica, em maio do mesmo ano, um Manifesto dos Gráficos contra a intervenção em seu sindicato, ${ }^{25}$ informando, pouco tempo depois, que "a sede da USTEP foi ocupada por tiras e pelegos policiais a serviço do agente imperialista Morvan", numa referência ao então ministro do Trabalho. ${ }^{26}$

Muitas lideranças do movimento foram perseguidas, exigindo-se atestados de ideologia para que pudessem concorrer às eleições sindicais.

Diante desse cenário, o PCB faz uma inflexão em sua política, deslocando-se para o campo mais à esquerda, às vezes um tanto distante da realidade. Sua proposta para os militantes operários foi no sentido de que se afastassem de uma atuação a partir dos sindicatos, criando organizações paralelas. Embora muitos ativistas desenvolvessem uma atuação mais ligada ao local de trabalho não deixaram, porém, de atuar nos sindicatos, adotando uma postura que ficou conhecida como de "dupla militância", estando presentes nas organizações oficiais e nas paralelas.

Em Pernambuco podemos visualizar esse posicionamento através da atuação

22 BEZERRA, Gregório. Memórias (segunda parte: 1946-1969). Rio de Janeiro: Civilização Brasileira, 1979, p.33.

23 SILVA, Fernando Teixeira da; SANTANA, Marco Aurélio. "O equilibrista e a política: o "Partido da Classe Operária” (PCB) na democratização (1945-1964)”. In: FERREIRA, Jorge; DELGADO, Lucília de Almeida Neves (orgs.). O tempo da experiência democrática: da democratização de 1945 ao golpe civil-militar de 1964. Rio de Janeiro: Civilização Brasileira, 2003. (O Brasil Republicano; v. 3) p.114.

24 Folha do Povo, Recife, 16 jan. 1947. A USTEP era a União Sindical dos Trabalhadores do Estado de Pernambuco.

25 Folha do Povo, Recife, 04 maio 1947.

26 Folha do Povo, Recife, 11 maio 1947. 
dos gráficos, cujo sindicato sofreu intervenção em 1947, só sendo retomado em 1953. Assim é que, em março de 1948, é lançado o Boletim Gráfico, órgão do Comitê Unitário e Progressista dos Trabalhadores Gráficos de Pernambuco, o que comprova a existência de uma entidade paralela. Esse jornal destaca a falta de respeito aos direitos da categoria, fazendo várias denúncias, inclusive uma em particular, sobre a desigualdade de gênero, já que, como é sabido, salários mais baixos pagos a mulheres e menores rebaixa o salário de toda a categoria. Como segue:

A falta de higiene nas oficinas gráficas é total e continua ignorada dos fiscais do Ministério do Trabalho e dos "comandos" da Saúde Pública. Os gráficos que trabalham à noite não se alimentam convenientemente porque não há refeitórios, como determina a lei (...). O problema dos salários é, porém o maior de todos (...). É ilegal a desigualdade nos preços dos salários dos especialistas de casa para casa e de sexo para sexo. Como o é também a colocação de menores em indústria insalubre como a gráfica. ${ }^{27}$

Esses problemas continuarão ao longo desse período, pois a categoria só conseguiu organizar uma greve no ano de 1963, paralisando totalmente todas as oficinas e jornais do estado, garantindo diversas conquistas. Nessa época o presidente do sindicato era Edvaldo Ratis.

Chama a atenção outro artigo, na primeira página do boletim, a respeito do imposto sindical, que assim se inicia: "Uma das reivindicações mais urgentes e por conseguinte digna do mais justo apôio por parte dos companheiros gráficos, é o não pagamento indébito e desnecessário do imposto sindical" ${ }^{28}$ e que vai ser criticado por diversas vezes durante o período Dutra.

No prontuário de Edvaldo Ratis foram encontrados dois esboços de artigos manuscritos pelo mesmo. No primeiro, intitulado "Recuperemos a autonomia sindical", o autor denuncia os sindicatos como "subseções do Ministério do Trabalho" e não órgãos de defesa dos direitos da classe. E prossegue:

Já não são mais aqueles sindicatos de antes de 1937: o trágico 1937, em que a ditadura covarde de Getúlio Vargas lançou o seu primeiro golpe contra os trabalhadores, solapando a sua autonomia ou liberdade sindical. Antes podíamos ter um sindicato realmente a serviço da classe, com dirigentes por nós escolhidos livremente, sem a chamada "intervenção" do governo, tendo-se também o direito de conservá-los, por vontade da maioria quando constatada a sua dignidade como dirigente operário.

Hoje, porém, apesar de termos saído daquela ditadura graças à mobilização de nosso povo ao lado das democracias, estamos, talvez numa ditadura mais cruel e mais tirana, apesar de termos uma Constituição que nos lega o direito de livre reunião, de liberdade de pensamento e palavra, e de autonomia sindical. Tudo isto apenas no papel, pois nos falta o cumprimento por parte os mais responsáveis - os representantes do povo - cuja maioria reacionária e submissa, estraçalha os mais justos direitos aos trabalhadores, tão dificilmente conquistados por aquela minoria popular e democrática, que honrosamente tiveram assento no parlamento nacional - os representantes comunistas. $(. . .)^{29}$

O Sindicato dos Gráficos foi efetivamente fundado em 1934, a partir de uma associação anterior chamada de Aliança dos Trabalhadores Gráficos. Seu primeiro

27 Boletim Gráfico. Recife, 15 mar. 1948. Fundo SSP/DOPS/APEJE. Prontuário Edvaldo Ratis, nº 18.439.

28 Boletim Gráfico. Fundo SSP/DOPS/APEJE. Prontuário Edvaldo Ratis, nº. 18.439.

29 Recuperemos a autonomia sindical. Fundo SSP/DOPS/APEJE. Prontuário Edvaldo Ratis, nº 18.439. 
presidente, Sindulfo Correia Josué, ligado aos comunistas, incorporava a tradição de luta da categoria. O golpe do Estado Novo instalou a ditadura Vargas, mas, na verdade, a repressão aqui já era grande até por ter sido um dos estados envolvidos no levante comunista de 1935, fato não reportado por Ratis. Ao mencionar que, devido aos limites impostos aos trabalhadores pelo governo Dutra, se pudesse estar numa "ditadura mais cruel e mais tirana" pois "estraçalha os mais justos direitos aos trabalhadores", o autor, embora com certo exagero, desnuda os limites impostos a nossa jovem democracia. É interessante ressaltar que em Pernambuco, ao longo dos anos 1950, prisões e perseguições políticas foram constantes, particularmente contra trabalhadores e militantes comunistas.

Já em 1949, Ratis assina outro manuscrito, desta vez contra a Lei de Segurança em apreciação no Congresso Nacional. Após algumas ponderações a respeito, diz ele que a lei

Na prática significa o completo esmagamento de todas as liberdades do operariado faminto e miserável do Brasil. Esta lei, que si aprovada significa também dias mais negros de fome, de tuberculose e de mortalidade infantil, tudo isto em maior escala que atualmente, merece desde já o repúdio por parte não somente do operariado mas também de todo cidadão livre e democrata. (...)

Com a Lei de Segurança em vigor, naturalmente não poderemos lutar contra os salários de fome, contra a carestia e o câmbio negro, contra o roubo de nossos salários através do imoralíssimo Imposto Sindical, pelo respeito e aplicação do direito operário, pela defesa de nossas riquezas minerais, por aumento de salários e por um governo popular.

Eis porque, no momento é dever patriótico de todo operário, de toda dona de casa e de todo cidadão livre, lutar organizadamente contra esta Lei de Segurança que representa para nós o amordaçamento completo de todas as liberdades. (...)..$^{30}$

Desta feita, o autor utiliza uma linguagem mais adequada com vistas a sensibilizar os leitores, lembrando a fome, a tuberculose, a mortalidade infantil, companheiras diuturnas dos trabalhadores em Pernambuco, cujos salários eram normalmente muito baixos e as condições de vida e trabalho bastante precárias. Também não perde a oportunidade, ao falar dos salários, de contrapor-se à cobrança do imposto sindical, que trata como algo imoralíssimo, um roubo. A campanha contra o pagamento desse imposto era parte da política do PCB nesse período, que denunciava, como já foi visto, o atrelamento dos sindicatos ao Estado, o que era mantido também por conta do dinheiro gerado por esse imposto e que servia para fornecer recursos aos sindicatos, independente de serem comprometidos com os interesses e as reivindicações de suas respectivas categorias. A defesa das riquezas minerais do país é algo que também sensibiliza, e os desdobramentos desse compromisso serão melhor percebidos a partir dos anos 50 quando se torna massiva a campanha para que a exploração e controle do petróleo seja feita pelo Estado brasileiro. Por fim, o chamamento à luta engloba especificamente as donas de casa. Ora, naquele mesmo mês de março estava sendo realizando no Recife o Congresso das Mulheres pela Paz, que resultou na fundação da União Feminina de Pernambuco, a qual se propunha, entre outras coisas, a lutar contra o alto custo de vida, pela defesa dos direitos civis, políticos e econômicos das mulheres, assim como tratar de problemas gerais de educação e cultura, de assistência social, maternidade e infância. ${ }^{31}$ 
Com a eleição e posse de Vargas na Presidência da República em 1950 foi possível uma certa abertura com relação à participação dos trabalhadores nos sindicatos, em especial no caso dos comunistas. Em 1952, o Comitê Nacional do PCB estabeleceu uma resolução que "orientava sua militância a efetivar alianças com outros grupos e indicava o retorno aos sindicatos oficiais". ${ }^{32}$ Ou seja, o partido reconhecia que não havia condições para criar um outro movimento sindical com base na formação de organizações paralelas, conforme proposto em 1947.

No caso dos gráficos de Pernambuco, a tentativa de atuação no sindicato já vinha acontecendo desde 1951. Assim é que, em $1^{\circ}$ de maio daquele ano, é publicado o primeiro número do jornal O Gráfico, como órgão oficial do Sindicato dos Trabalhadores nas Indústrias Gráficas de Recife. Contando com quatro páginas, traz artigos assinados por alguns militantes do partido, entre os quais Edvaldo Ratis. No expediente consta como diretor da publicação Severino de França, como secretário Edvaldo Ratis e como gerente Sindulfo Correia Josué. Sua sede corresponde ao próprio endereço do sindicato, Rua do Imperador, 370, $1^{\circ}$ andar. É importante ressaltar, contudo, que as disputas entre os comunistas e a diretoria interventora de então são assumidas claramente. Assim é que o artigo de Ratis na verdade é a transcrição do discurso que o mesmo proferiu por ocasião da comemoração do aniversário do sindicato, intitulado "Conquistemos Nossa Liberdade Sindical", no qual faz denúncias sobre o comportamento do então presidente, Clementino Pontes, e afirma: "A diretoria é democrática, mas não foi escolhida pela classe". Em resposta ao seu discurso, o representante da Confederação Nacional dos Trabalhadores, Fiúza Lima, chama-o de "fogoso" e "idealista sem rumo certo". Ratis, porém, é defendido pelo orador seguinte. ${ }^{33}$

Foi o jornal Folha do Povo que trouxe alguns elementos capazes de esclarecer melhor o motivo de tanta celeuma por meio de uma nota assinada pela corporação gráfica do Diário da Manhã. A mesma informava que a diretoria em exercício fora eleita num processo em que uma segunda chapa (que então se deduz ser aquela ligada aos comunistas) fora impedida de se registrar. E novamente, quando da eleição dos representantes dos gráficos para as Juntas de Conciliação e Julgamento, foram registrados como candidatos o presidente, o secretário e uma terceira pessoa de fora da categoria; apesar de ter sido possível formalizar uma chapa alternativa, esta foi impugnada pela diretoria de então. E conclui:

Os gráficos do Recife precisam deliberar alguma coisa contra esta desmoralização do nosso sindicato.

Será justo abandoná-lo?

Pensamos que não. Mas podemos reagir de maneira mais eficiente.

Já existem as delegações de oficinas. Elas devem discutir o assunto com os demais colegas.

Sugerimos que as delegações de oficina passem a recolher as contribuições do sindicato à Caixa Econômica, em nome dos trabalhadores de cada empresa e que uma comissão composta de representantes de todas as corporações do Recife passe a trabalhar PELA DESTITUIÇÃO DA ATUAL DIRETORIA DO SINDICATO e por novas eleições. E que somente

Recife dos anos 50". Esboços - Revista do Programa de Pós-graduação em História da UFSC, Florianópolis, nº 17, pp. 91-110, 2007. Em nível nacional foi fundada, também em 1949, a Federação de Mulheres do Brasil. 32 SILVA e SANTANA. "O equilibrista e a política", p.118.

33 O Gráfico, Recife, 1 maio 1951, p. 1, Fundo SSP/DOPS/APEJE. Prontuário Edvaldo Ratis. n 18439. 
depois de termos eleito uma direção que de fato represente, em todos os sentidos, a classe gráfica o Recife, seja o dinheiro guardado na Caixa Econômica entregue ao tesoureiro do Sindicato. (...). ${ }^{34}$

Ora, por este texto confirmamos a existência de organizações por local de trabalho, cuja construção era uma proposta para ser implementada sob orientação e atividade dos comunistas, assim como percebemos a presença de militância de esquerda no Diário da Manhã. Aliás, Edvaldo Ratis foi funcionário dessa empresa, assim como do Correio do Povo e, a partir de 1963, do jornal Última Hora.

Como o sindicato só foi retomado nas eleições de 1953, é de se supor que essa proposta não tenha tido a repercussão desejada. De qualquer modo, expressa uma tentativa de resistência ao peleguismo incrustado em muitos sindicatos no período.

Com a retomada do sindicato com base em uma frente, O Gráfico torna-se seu órgão de comunicação, tendo, de início, periodicidade mensal. Em seu primeiro número foi publicado artigo que expressa a visão hegemônica nesse momento. Assim diz o artigo:

(...) Queremos nesta nova fase de vida, guiar os nossos colegas pelo caminho mais claro a seguir, procurando, antes de tudo, a fórmula que os aproxime da classe patronal, indubitavelmente mais forte que a dos trabalhadores, fazendo assim com que haja compreensão entre as classes que mutuamente se precisam.

E enquanto o Sindicato dos Gráficos agir como órgão moderador preventiva e repressivamente contra atos que venham denegrir a nossa posição de seres humanos estaremos alertas apontando as injustiças cometidas de ambas as partes, e enaltecendo-as quando se fizer necessário. Esta será a nossa política, Não adotaremos dogmas nem partidos políticos, quer sejam da esquerda ou da direita. Não pediremos senão aquilo a que temos direito. Não queremos lançar mão das reservas econômicas da classe patronal. Também combateremos a exploração do homem pelo homem nas mais variadas formas por que se apresentam. (...). ${ }^{35}$

Ora, conseguir tirara diretoriaanterior diretamenteligadaaointervencionismo do Ministério do Trabalho e ter outra eleita diretamente pela classe é muito importante. Contudo, com base nas posições acima expressas, percebe-se que dificilmente se incentivaria mobilizações mais ostensivas. De qualquer modo, os comunistas conseguem ir construindo aí um espaço maior de atuação.

Apesar de não compor a diretoria nem o expediente do jornal, o que só virá a ocorrer a partir do ano seguinte, Ratis escreve no mesmo como colaborador. Em seu segundo número assina artigo sobre $01^{\circ}$ de Maio, fazendo, inicialmente, um chamamento no qual estão presentes importantes bandeiras de luta levadas pelo $\mathrm{PCB}$, tais como "a continuidade de suas lutas [dos trabalhadores] pela unidade e autonomia sindicais; pelo aumento dos miseráveis salários; contra a carestia de vida e pela paz entre todos os povos". ${ }^{36}$

Ao longo dos anos 50 foram inúmeras as ocasiões em que os trabalhadores protestaram contra o aumento dos preços dos gêneros de primeira necessidade. Em São Paulo, centro da atividade fabril do país, já na greve dos 300 mil, ocorrida em março de 1953 e que contou com a participação de metalúrgicos, 
têxteis, vidreiros, gráficos e marceneiros, essa questão foi colocada, o que se repetiu nas outras grandes greves como a dos 400 mil, ocorrida em outubro do ano seguinte. Nesta, além do aumento de salário, constituía uma das reivindicações a "aplicação da tabela da COAP para o preço da carne e impedimento de qualquer aumento nos preços de gêneros alimentícios e bens de consumo popular". ${ }^{37}$ Merece destaque, também, a iniciativa de se formar, a partir desses movimentos grevistas e de outros posteriores, uma nova estrutura que congregasse diferentes categorias, o que forçosamente significava um rompimento com a estrutura sindical oficial que só permitia instâncias superiores separadas por categoria, no caso as federações e confederações. Assim é que se formou inicialmente o Pacto de Unidade Intersindical - PUI e o Pacto de Unidade e Ação - PUA, em 1957.

Em que pese o fato de nesse período os gráficos de Pernambuco não terem deflagrado nenhuma greve, a questão dos baixos salários e do alto custo de vida era sempre tocada, ora como denúncia, ora como análise. A palavra de ordem proposta pela categoria em 1953 foi: "CONTRA A FOME, A CARESTIA DE VIDA E A EXPLORAÇÃO SÓ VALERÁ A NOSSA FORÇA ORGANIZADA". ${ }^{8} \mathrm{O}$ acordo firmado com os patrões, mediado pelo Delegado Regional do Trabalho, foi considerado pouco satisfatório em relação ao pleiteado. Porém, até maio do ano seguinte continuaria a valer o acordo feito pela diretoria anterior, que tinha a duração de dois anos.

Ainda no final daquele ano o sindicato iniciou a campanha pelo pagamento de um abono de Natal, encaminhada sob a forma de um pedido ao sindicato patronal, o que, novamente, demonstrava os limites desses dirigentes no sentido de partir para uma pressão maior ao patronato.

Contudo, em janeiro, os trabalhadores do Recife fizeram uma grande manifestação, assim retratada por Ratis:

Já não é mais preciso se falar sobre a situação de miséria que atravessamos. Capital e trabalho são como água e azeite: nunca se misturam. Enquanto a cidade se cobre de luz e festas, milhões de pessoas morrem à falta de hospitais. A pobreza continua abandonada, prevalecendo, ainda, as palavras do "senhor todo poderoso" - quem não pode viver, morre" (e ele morreu). Os donos do poder e do ouro não ouvem o clamor do povo. Mas o povo sente as pressões e vai aprendendo a resolver os seus próprios problemas. Já não acredita nos falsos salvadores nem nos bafejos purulentos dos políticos inescrupulosos que outra classificação não merecem, se não a de escroques dos cofres da nação. Por isso, infelizmente, eles tiveram que assistir às manifestações do dia 28, no Parque Treze de Maio, em prol de um salário mínimo de $\mathrm{Cr} \$ 1.600,00$ e do congelamento dos preços. Foi a voz do povo que se fez ouvir (...).

Toda aquela massa que se comprimia No Parque Treze de Maio foi, também, uma advertência de que o grito de fome é pior que o de guerra. (...). ${ }^{39}$

37 LEAL, Murilo. A reinvenção da classe trabalhadora (1953-1964). Campinas: Editora da Unicamp, 2011, p. 268. Essa mesma obra traz importantes informações sobre essas greves e as formas de organização dos trabalhadores de São Paulo no período.

38 O Gráfico, Recife, set. 1953, p.3.

39 O Gráfico, Recife, dez. 1953 e jan. 1954, p.1 e 3. 
Apesar desse artigo inflamado, o que é possível perceber quando o autor torna um grito de fome maior do que um de guerra, posicionando-se de forma claramente contrária àquele editorial bem comportado da diretoria no início de 1953, Edvaldo Ratis, a partir de abril de 1954, passa a compor o expediente do jornal como secretário. Mudanças na conjuntura nacional também devem ter contribuído para essa nova posição. Afinal, o salário mínimo por longo tempo não tivera aumento, enquanto a inflação corroía seu valor.

Essa manifestação, que contou com a participação de trabalhadores do Recife e de vários municípios próximos à capital, foi organizada pelo Conselho Consultivo dos Trabalhadores ${ }^{40}$ e fazia parte da campanha pela reforma do salário mínimo, sendo fruto de um amplo movimento levado pelos sindicatos com vistas a apressar a decretação de um novo salário a ser proposto pelo então ministro do Trabalho, João Goulart, o que veio a ocorrer em maio do mesmo ano por meio de um decreto do presidente Getúlio Vargas.

Nesse mesmo número aparece, em destaque, a seguinte conclamação:

\begin{abstract}
A Federação Nacional dos Gráficos tem em seu nascedouro uma importante tarefa a cumprir; assim esperam os gráficos do Recife: Coordenar os companheiros gráficos do Brasil através de seus sindicatos a unirem-se de norte a sul, em movimento nacional de relêvo, na luta pela decretação do salário mínimo votado pelas respectivas comissões nos Estados, pelo congelamento dos prêços das mercadorias e pela consequente abertura de nossas relações comerciais com todos os países do mundo. ${ }^{41}$
\end{abstract}

Dessa forma os comunistas iam se articulando em prol dos seus direitos, ampliando sua presença no meio sindical mais geral, propondo uma atuação política mais direta em relação ao Estado e, ao mesmo tempo, procurando criar condições para um futuro reatamento de relações com a URSS.

“Devem os sindicatos representarem-se nos Parlamentos"? Esta questão, colocada pelo jornal em novembro de 1953, na verdade procurava preparar a categoria para as eleições que viriam. O Comitê Eleitoral que se formava partia da ideia de que "o trabalhador gráfico deve possuir a sua maioridade política. Esta maioridade a teremos conquistado, quando realizarmos a nossa Convenção para escolha dos elementos que deverão representar a nossa classe na Câmara Municipal do Recife e, se possível, na Assembleia Legislativa". ${ }^{42}$ O representante indicado para a Câmara dos Deputados foi o então presidente efetivo do sindicato, Severino Manoel de França.

Grande esforço era feito também com vistas a convencer os companheiros a regularizarem seus títulos eleitorais, assim como dos familiares e amigos, para que pudessem tomar parte no pleito a realizar-se no dia 3 de outubro. Apesar do esforço, o candidato dos gráficos não conseguiu se eleger. No ano seguinte, porém, os gráficos continuavam tentando eleger pessoas da categoria, desta feita para a Câmara de Vereadores. Os nomes apresentados eram, além do presidente, Wilson Carvalho da Silva, o de Edvaldo Ratis. ${ }^{43}$ Este atuava não só no sindicato, mas também no Sesiano Clube de Água Fria, bairro onde residia. Novamente os indicados não foram eleitos. No jornal não aparece 
nenhum artigo que faça uma análise a respeito. É de se supor que a categoria não fosse numericamente significativa e que os candidatos não tivessem apoio de outros setores.

Wilson Carvalho era ligado ao Partido Socialista Brasileiro. No caso de Ratis, assim como de outros comunistas, ao se candidatarem o faziam por outras legendas, geralmente pequenos partidos que funcionavam como siglas de aluguel. Nas eleições de 1950, por exemplo, foi através do Partido Social Progressista - PSP que os comunistas se candidataram. Esses expedientes, porém, não eram simples, pois havia, dependendo da conjuntura, cerrada pressão com vistas a impedir que as candidaturas se viabilizassem. Neste caso, o Partido de Representação Popular - PRP usou o argumento de que os candidatos não eram ideologicamente filiados ao PSP. 44 Já nas eleições de 1954 os "candidatos populares", como eram denominados os comunistas, concorreram pelo Partido Trabalhista Nacional - PTN. Novamente o Partido da Representação Popular - PRP, que aglutinava os fascistas, tentou impugnar as referidas candidaturas, mas não conseguiu. Quando isso acontecia, os agentes do DOPS partiam para a pressão, ou repressão, na tentativa de impedir o funcionamento das oficinas da Folha do Povo, onde seria impresso o material de divulgação dos candidatos.

A partir de meados dos anos 50, a atuação política dos comunistas foi se ampliando com a formação da Frente do Recife, fruto de uma aliança entre os partidos mais à esquerda - PCB, PSB e PTB - com vistas à eleição do prefeito do Recife. Por vários motivos o Partido Social Democrático - PSD, no poder há muitos anos, era visto como o agrupamento político mais conservador, representando os interesses dos grandes "coronéis" do interior de Pernambuco. Diversos membros da União Democrática Nacional - UDN apoiam essa articulação, que termina com a vitória do socialista Pelópidas da Silveira. Sua dinâmica administração, efetivamente comprometida com os interesses da população mais pobre, abre as portas para a participação dos movimentos populares organizados.

Em 1957, começa a se articular um movimento, posteriormente denominado de Oposições Unidas, com vistas a tomar o governo das mãos dos pedessistas, com base em um programa que defendia a necessidade de promover a industrialização no estado. Desta feita a UDN vai assumir a liderança da composição, indicando o candidato ao governo de Pernambuco, Cid Sampaio, que é eleito. Ao longo do seu governo, porém, as contradições presentes numa frente que unia de usineiros a comunistas, foi se tornando inviável. 45

As eleições seguintes, tanto para prefeito como para o governo do Estado vão pendendo sempre para a esquerda, sendo consagrado nas urnas Miguel Arraes, inicialmente para prefeito e, posteriormente, para governador, o que vai criando uma nova conjuntura, favorável à participação política dos setores democráticos e populares e, particularmente, dos trabalhadores, o que vai ter um rebatimento nas mobilizações das diferentes categorias.

Nos anos 50, Pernambuco não era um estado no qual os trabalhadores conseguiam enfrentar os patrões de forma mais radical. O que vimos com os gráficos acontecia também com muitas categorias, que, apesar de intensamente exploradas, não conseguiam força suficiente para fazer greves. Nesse sentido, o mais comum era que fossem assinados acordos, mediados muitas vezes pela

44 Para maiores detalhes, trazendo elementos curiosos, consultar CAVALCANTI, O caso eu conto como o caso foi, p.p.133 a 138.

45 PANDOLFI, Dulce Chaves. Pernambuco de Agamenon Magalhães: consolidação e crise de uma elite política. Recife: Fundação Joaquim Nabuco - Editora Massangana, 1984. 
Delegacia Regional do Trabalho. A categoria mais forte eram os têxteis, concentrados em algumas grandes fábricas no Recife e em outras cidades próximas da capital, como Paulista, Moreno e Camaragibe. Assim é que houve uma grande paralisação desse setor em 1952, que durou uma semana, e outra em 1958, dessa feita levada a cabo apenas pelo sindicato do Recife, e que teve a duração de 42 dias. No final foi feito um acordo acertado pelo Tribunal Regional do Trabalho, e que concedia $25 \%$ de reajuste, embora as empresas consideradas deficitárias fossem excluídas dessa obrigação. Os patrões apelaram e o Tribunal Superior do Trabalho baixou o reajuste para $18 \%$. Houve punições generalizadas, com muitos trabalhadores demitidos. O desconto das mensalidades do sindicato, feito já na folha de pagamento das empresas, foi cortado. Nova greve só veio a ocorrer em 1963.46

Mas, nesse mesmo ano de 1958, realiza-se no Recife o I Congresso de Trabalhadores de Pernambuco, que contou com a participação de 34 entidades sindicais, inclusive o Sindicato dos Gráficos, fundando o Conselho Sindical dos Trabalhadores do Estado de Pernambuco - Consintra, responsável pela organização de importantes paralisações de caráter político no início dos anos 60, como a que foi feita para garantir a posse de João Goulart, ou mesmo uma de caráter mais específico, pela defesa da Sudene e de seu primeiro plano diretor. ${ }^{47}$

A essa altura os comunistas ampliam sua participação nas organizações sindicais em geral, em alguns casos em disputa com militantes da Igreja que atuavam a partir da Juventude Operária Católica. No campo, as Ligas Camponesas, atuantes desde a segunda metade dos anos 50, e assim como os sindicatos rurais ligados ao PCB também têm que disputar espaço com a Igreja, que atua por meio do Serviço de Orientação Rural de Pernambuco - Sorpe, tendo como propósito se aproximar dos trabalhadores rurais e impedir a influência do "comunismo ateu". ${ }^{48}$

Os comunistas já haviam conquistado a direção do Sindicato dos Gráficos em 1958, quando conseguiram formar uma chapa de unidade encabeçada por Sindulfo Correia Josué, tendo Edvaldo Ratis como secretário, que continua, como fazia todos os anos, a escrever sobre o dia $1^{\circ}$ de Maio. Em 1960, porém, o artigo não trata apenas dos mártires de Chicago, mas chama a atenção para as vitórias obtidas pela classe operária, assim como conclama para novas conquistas no campo do socialismo. Realça também a liberdade das ações que tiveram para realizar o I Congresso Sindical dos Trabalhadores do Norte e Nordeste, colocando "a necessidade de se unirem cada vez mais em torno de reivindicações urgentes e de medidas que abreviem o tão almejado desenvolvimento econômico da região". ${ }^{49}$ Essa questão, de promover o desenvolvimento do Nordeste, trata de um aspecto particularmente específico e que unia praticamente todos os segmentos políticos do estado. Como promover esse desenvolvimento é que os diferenciava: que tipo de mudanças sociais seriam imprescindíveis para implementar uma modernização que, desta vez, beneficiasse a maioria da sua população? O autor ainda realça que, no presente momento, "somente as soluções

46 ABREU E LIMA, Tecendo lutas, abrindo espaços, p. 92. Existem poucos estudos específicos sobre outros sindicatos têxteis em Pernambuco. Referência nesse sentido é a obra de LOPES, José Sérgio Leite. A tecelagem dos conflitos de classes na "cidade das chaminés". São Paulo: Marco Zero, 1988, sobre a fábrica de Paulista.

47 JACCOUD, Luciana de Barros. Movimentos Sociais e crise política em Pernambuco 1955-1968. Recife: Fundação Joaquim Nabuco - Editora Massangana, 1990.

48 ABREU E LIMA, Maria do Socorro de. Construindo o sindicalismo rural: lutas, partidos, projetos. Recife, Editora Universitária da UFPE, 2012.

49 O Gráfico, Recife, maio 1960, p.5. 
nacionalistas poderão romper os grilhões com que os trustes e monopólios estrangeiros nos querem escravizar". ${ }^{0}$

Em 1962, Edvaldo Ratis conquista a presidência do Sindicato dos Gráficos, após muitos anos de militância nem sempre favoráveis. Nos anos 50, chegou a encabeçar uma chapa de oposição, mas perdeu para o então presidente, do PSB, que foi reeleito. Ao invés de se afastar por uns tempos, como outros membros da chapa o fizeram, continuou escrevendo para o jornal e, dentro de certo tempo, voltou a fazer parte do seu corpo editorial.

Porém, o contexto agora era outro, tanto em termos nacionais como, particularmente, locais. Após o plebiscito sobre o parlamentarismo, Goulart assume a Presidência sem as amarras impostas por este sistema de governo. E, embora enfrentasse muitas dificuldades para implementar políticas mais progressistas, adotou medidas que favoreciam aos trabalhadores a partir dos pleitos e pressões destes. Assinou, em 1962, a lei que criou o décimo terceiro salário, e que veio a mobilizar muitas categorias exigindo o seu cumprimento por parte do patronato relutante. No que diz respeito aos trabalhadores rurais, e a presença desse setor era marcante particularmente na zona canavieira de Pernambuco, em 1962 regulamentou, através de uma portaria, o direito à sindicalização rural, assim como criou a Superintendência de Política e Reforma Agrária. Em 1963, foi aprovado pelo Congresso Nacional o Estatuto do Trabalhador Rural, garantindo aos assalariados rurais os direitos trabalhistas. Tudo isso teve muita repercussão em Pernambuco.

Pouco antes da votação do plebiscito, o jornal Última Hora/NE publica uma conclamação da Federação Nacional dos Trabalhadores Gráficos, recomendando que seus sindicatos filiados às associações profissionais e os trabalhadores gráficos dissessem não ao parlamentarismo e propondo as reformas de base:

Os trabalhadores devem dizer NÃO ao parlamentarismo, mas, ao mesmo tempo, reforçar a unidade de classe para dizer NÃO à miséria, à fome, ao analfabetismo e à ditadura financeira do capital espoliativo e imperialista, único responsável pela inflação que nos corrói dia a dia. (...)

Reforma agrária radical; reforma bancária progressista; reforma administrativa; reforma eleitoral; limitação efetiva e progressiva dos lucros para o exterior; política externa independente e autodeterminação dos povos; nacionalização das empresas e serviço público (estrangeiras e brasileiras); fortalecimento da PETROBRAS; reforma da legislação sindical; reforma da legislação trabalhista; diplomação e posse dos candidatos eleitos, sem discriminação de ordem política ou ideológica e anistia ampla para todos os dirigentes sindicais que estão sendo processados pela justiça de nosso país e revogação pura e simples da Lei de Segurança Nacional..$^{1}$

O teor dessa conclamação procura relacionar questões gerais e específicas, econômicas e políticas, ideológicas e sociais. Chama a atenção para aspectos democráticos importantes, que necessitariam ser implementados para se superar os limites da democracia que então se vivia, como o voto do analfabeto, a anistia a dirigentes sindicais, a revogação da Lei de Segurança Nacional.

O sentido da palavra NÃO, traduzido para o dia a dia da classe trabalhadora, significa a superação das precárias condições de vida da mesma, cuja responsabilidade cabe ao grande capital identificado como imperialista, acusado, inclusive, 
de ser o responsável pela inflação. Um forte viés nacionalista se coloca particularmente com a defesa da Petrobras.

O ano de 1963 começa, portanto, conclamando os trabalhadores e os setores democráticos a levar adiante grandes lutas. Miguel Arraes toma posse no final de janeiro com uma nova postura no entendimento do que significa ser governador, abrindo as portas do Palácio do Campo das Princesas, sede do governo estadual, para os trabalhadores urbanos e rurais, o que escandaliza as classes dominantes do estado. Ao longo de seu governo, o empresariado vai cerrar fileiras para denunciar tudo de positivo que é feito, em especial em defesa dos trabalhadores rurais. Para isso, a chamada grande imprensa assume um papel denuncista, com vistas a criar um clima de medo generalizado entre a população mais desavisada. Pernambuco é colocado como sendo uma Cuba em potencial. Reivindicar direitos é considerado "coisa e comunista".

Contudo, os trabalhadores partem para a ofensiva, de tal forma que, o que antes não se via torna-se, agora, lugar comum. As greves tornam-se frequentes, passeatas de trabalhadores rurais com suas enxadas e foices compõem, eventualmente, a paisagem urbana.

Júlio Barros ${ }^{52}$ em sua dissertação elaborou um quadro com todas as greves ocorridas durante o governo Arraes em Pernambuco, de 31 de janeiro de 1963 a 1 de abril de 1964: foram 91 greves, sendo 48 rurais e 43 urbanas. Uma mobilização tão intensa assim por certo tem a ver com a conjuntura, mas também significa que, ao longo do período anterior, lideranças mais comprometidas e dispostas ao enfrentamento foram se forjando.

A mobilização dos gráficos começou no mês de fevereiro, quando realizaram sua primeira assembleia. Foi elaborado um manifesto no qual eram expostas as razões pelas quais lutavam:

\begin{abstract}
A situação que ora atravessamos já não permite posições acomodatícias. Sofremos em nossa própria carne o problema da fome pela desvalorização dos nossos salários. O novo salário mínimo não é suficiente para a aquisição sequer de alimentos para nossas famílias. A ganância cada vez mais desenfreada dos exploradores do povo, dos tubarões, já não tem limites. O govêrno se mostra impotente para refreá-los. Medidas paliativas têm sido tomadas porém, nada resolvem de positivo. Este é o quadro real que sabemos pintar dentro da matemática doméstica. Enquanto isso nossos filhos passam fome, não podem comprar livros para estudar, andam mal vestido e descalços essa (sic) adoecem são capazes de morrer à míngua à falta de remédios.

Esse quadro é o cotidiano da nossa vida de operário, mal remunerado e explorado pelo patrão e pelos tubarões. Isto não pode nem deve continuar. É preciso que nos unamos, todos dentro do nosso Sindicato, para exigir um salário condigno para a classe gráfica.

(...) Os patrões podem e devem pagar um salário diário que honre a nossa qualidade de profissionais. ${ }^{53}$
\end{abstract}

Os problemas elencados no manifesto vêm de longa data, e suas causas são atribuídas aos baixos salários, particularmente o mínimo. No último parágrafo, porém, a categoria coloca uma questão já levantada em outros anos, qual seja, a

52 BARROS, Júlio César Pessoa de. “Conflitos e negociações no campo durante o primeiro governo de Miguel Arraes em Pernambuco (1963-1964)”. (Dissertação de Mestrado, Universidade Federal de Pernambuco, 2013).

53 O Gráfico, Recife, fev. 1963, p.1. 
falta de um salário profissional. Os gráficos viam-se como trabalhadores especializados, que deveriam ter um reconhecimento social expresso em um salário digno, também por conta de sua profissão.

Ao fazer a distinção entre o patrão e o tubarão, entendemos que, além da exploração promovida pelo patronato existia outra; fruto dos lucros descabidos dos comerciantes, exploradores do povo, responsáveis pela inflação e a quem o governo não conseguia controlar. Afinal, a carestia de vida sempre foi denunciada pelos trabalhadores, muitas vezes, colocada como pauta de negociação em suas campanhas salariais.

Por fim, é importante ressaltar alguns dos itens elencados como exemplos de suas necessidades, quais sejam: a falta de livros para estudar e o fato de andarem mal vestidos. É possível que os operários como um todo se preocupassem com esses itens. Para os gráficos, porém, a privação do estudo poderia ser sentido de forma mais intensa.

Na mesma edição foi publicada uma matéria que explicava o motivo pelo qual o dia 7 de fevereiro era considerado o Dia do Gráfico. A data refere-se à deflagração de uma greve ocorrida em 1923, que teve a duração de 45 dias, na qual os trabalhadores enfrentaram prisões e torturas, mas que conseguiu ser vitoriosa. $\mathrm{E}$ conclui: "Que os atuais trabalhadores tomem esse exemplo, peguem esta bandeira e caminhem para frente em defesa de seus direitos conspurcados". ${ }^{4}$

A greve foi deflagrada, durou 20 dias, de 21 de março a 9 de abril. A categoria conquistou $75 \%$ de aumento e parou totalmente a circulação dos jornais da cidade. No acordo ficou acertada a não punição dos grevistas e o pagamento de 50\% dos dias de greve em quatro prestações, regulando-se igualmente o pagamento dos aprendizes gráficos. Estipulou-se o salário mínimo profissional, entre outras cláusulas específicas à profissão. ${ }^{55}$

Com o golpe militar de 1964, boa parte da liderança sindical e popular de Pernambuco foi presa, Edvaldo Ratis entre eles. Apesar de torturado, como já foi dito, logo depois de ser solto voltou a ser visto numa reunião no Sesi, localizado no bairro onde morava. Provavelmente retomando suas atividades menos comprometedoras.

Recebido em 27/07/2016

Aprovado em 31/10/2016 
